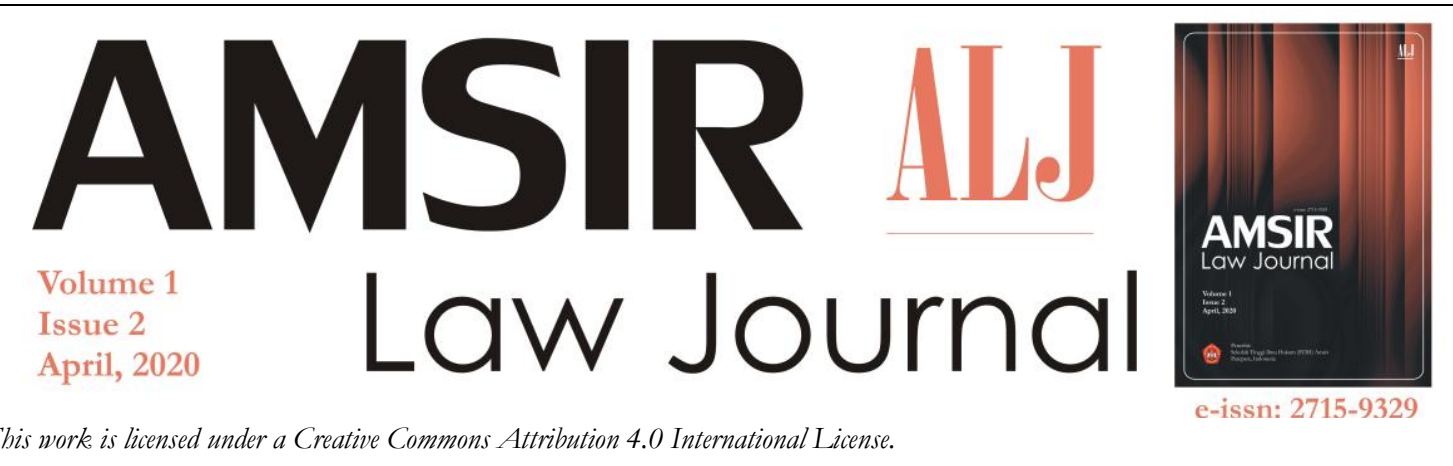

\title{
The Region Governance Review of Barru Regency to Actualize Good and Clean Governments
}

\author{
Aksah Kasim, ${ }^{1}$ Andi Heridah ${ }^{2}$
}

\begin{tabular}{l} 
ARTICLE INFO \\
\hline Keywords: \\
Capacity Improvement, Region \\
Government, Good Governance \\
and Clean Government, \\
Regional Autonomy. \\
How to cite: \\
Kasim, Aksah., Heridah, \\
Andi. (2020). The Region \\
Governance Review of \\
Barru Regency to Actualize \\
Good and Clean \\
Governments. Amsir Law \\
Journal, 1(2), 61-69. \\
DoI: \\
10.36746/ alj.v1i2.25
\end{tabular}

The factors of the region governance review of Barru regency to actualize good governance and clean government are the region the government have not applied the equity properly and optimally, uphold the rule of law, worked effectively, effectivity, and accountability, and formulated and implemented the strategic vision. This study is expected to explain, find, and describe the regional governance review in Barru Regency to actualize for good governance and clean government in the implementation of regional autonomy.

\section{Pendahuluan}

Giving the widest possible autonomy for regions is one of the ways to accelerate the realization of welfare for society through service improvement, empowerment, and participation. Autonomy in the strategic government of globalization expects to increase competitiveness by focusing on the principles of democracy, equity, justice, privilege, specificity for potency and diversity in the system of the Unitary State of the Republic of Indonesia.

In a unitary state, sovereignty is only in the state or national government but it is not in the regional government so that the autonomy authority of the regional government is still in the national government for its decision.

Sekolab Tinggi Ilmu Hukum (STIH) Amsir, Indonesia.

Sekolah Tinggi Ilmu Hukum (STIH) Amsir, Indonesia. 
As the region is the unity of society that has autonomy, authority to regulate region based on the aspirations and interests' societies as long as it does not have a conflict with the national law national order and public interests.

National Government in policies must focus on region wisdom and acceleration by the Regional Government. Conversely, Regional Government should focus on Regional Regulations and other policies based on national interests. Therefore, it actualizes the balance between national interests That way a balance will be created between national interests and the synergy between regional and national governments.

The policies are made and conducted by the government that is the integral from national policies. The differences are the way to utilize the wisdom, potential, innovation, competitiveness, creativity and regional acceleration in achieving national goals which will support the achievement of national goals as a whole.

Good governance and Clean Government are the government whose development priorities are to improve performance, to improve the quality of services for society, and to reduce of abusing authority for the government apparatus. Good governance and Clean Government are always guided by the Constitution of the Republic of Indonesia 1945, the values of Pancasila and also the applicable law.

The development of a good government system, it should be transparency, accountability, feedback, and having the role of society. For the law contexts, good governance is the basic principle to know as the general underpinnings of government as a bridge between law norms and ethical norms.

The status quo of Indonesia government is still low as a standard of good governance and a clean government. The implementation for the regional government has not prioritized the development that leads to improve the performance, to apply the quality of service for the society, and to reduce the level of abuse for authority within the government apparatus.

Based on the problems as the phenomena mentioned above, it is necessary to confine the problems especially the regional government review in Barru Regency to actualize good governance and clean government for the implementation of regional autonomy nowadays.

\section{Metode}

This research is empirical legal research. ${ }^{3}$ The location of the study was conducted at region Barru Regency. The selection of location was based on the consideration that in this location was look actualize good governance and clean government for the implementation of regional autonomy nowadays. The data obtained both primary data and secondary data by logical deduction (syllogism) is an analysis shown by the data in following the theoretical basis for understanding the nature of facts or symptoms that apply both positive and normative. Descriptively, it elaborates, describes, and explains with the problems that are closely related to this study.

\section{The Regional Governance in Barru Regency Conducted Good Governance and Clean Government}

In the dictionary, the terms of "governance" and "government" commonly have the same meaning. The meaning is implementation the of authority in organization, institution, or

\footnotetext{
3 Butarbutar, Elisabeth Nurhaini. (2018). Metode Penelitian Hukum (Langkah-Langkab untuk Menemukan Kebenaran dalam Ilmu Hukum), Bandung: PT. Refika Aditama, p. 95.
} 
state. Government is one of the terms that is given for the identity to carry out governmental power in the state.

Based on Muin Fahmal explained that the indicator of clean government is a norm while the indicator of good governance is the government conducted the planning for three aspects such as the society as the community as connoisseurs, entrepreneurs as aspirators and the government as facilitators by implementing transparent, participatory, responsible, effective and equity governance.

In line with Effendi (2005) stated that "There is the elements of democracy, equity, transparent, rule of law, participatory and partnership". It can be concluded as a definition based on IIAS is "The process whereby elements in society wield power and authority and influence and enact policies and decisions concerning public life, economic and social development."4

In Indonesia, the governance issue begins to debate to demand the changing wether it ii the government or society. Besides Tangkilisan urged that "the concept of Governance, the government is only an actor to decide the policy. The role of government is as the developer or provider of services and infrastructure to create an environment that can facilitate other stakeholders to participate in policy". ${ }^{5}$

The correlation of regional decentralization and autonomy describes in the explanation of Gerald S. Maryanov stated that the regional decentralization and autonomy are like two sides in one coin. Based on the perspective of central government illustrated the implementation of decentralization in the Unitary States of the Republic of Indonesia while Regional Government is as regional autonomy. ${ }^{6}$

The success of regional autonomy is highly dependent on the regional government, namely the DPRD, district head, regional members, and society to work hard, skilled, disciplined, and behaves for values, norms, and morals, as well as the provisions of the applicable laws and regulations. The regional autonomy policy in 2001, it can be seen as a part of the change process. If the change is only for the regional policies and it explains in the regulation of number 32 and 2004 year then it is revised again in the regulation of number 12008 year, and revised again three times in regulation of number 23 and 2014 year. It can be concluded that democracy would never happen in Indonesia.

The principles of participation actualize good governance that is conducted through public service. It has a new perspective to improve public service in putting the society is not only as a customer but also as an owner of the government.

By giving a chance for the society to know more about the information of government so that it can facilitate the efforts of the community in assessing the government's alignments to the public interest. The public can easily determine whether to support the government or not because the criticism and protests carried out the government is more pro-public interest.

\subsection{Equity}

In the implementation of regional government based on the constitution of the Republic of Indonesia, regional governments manage and regulate according to the principle autonomy and assistance tasks, those are directed actualize fastly the welfare societies through the service improvement, empowerment a participation societies, and regional competitiveness

\footnotetext{
Uchana, Efendy Onong. (2005). Ilmu Komunikasi Teori dan Praktek. Bandung: Remaja Rosda Karya, p. n.p.

Tangkilisan. (2005). Manajemen Publik. Jakarta: Grasindo, p. 65.

Tjokroamidjojo, Bintoro. (1984). Pengantar Administrasi pembangunan. Jakarta: LP3ES, p. 15.
} 
by taking the principle of democracy, equality, equity, privilege, and the uniqueness of regionals in the system of the Unitary State of the Republic of Indonesia.

Based on the explanation, the principle of equity is the accelerator for good governance and clean government at Barru Regency that can be seen through the questionnaires. There are 90 (ninety) respondents that consist of government officials, subdistrict heads, village heads, and urban village heads in Barru Regency as following:

Table 1. The Classification of Respondents' Answers towards "The Principles of Equity" as an Accelerator for Good Governance and Clean Government in Barru Regency

\begin{tabular}{lcc}
\hline \multicolumn{1}{c}{ Description } & F & Sum \\
\hline Very Effective & 8 & $\mathbf{P ~ ( \% )}$ \\
Effective & 28 & 08,89 \\
Less Effective & 43 & 31,11 \\
Ineffective & 11 & 47,78 \\
\hline \multicolumn{1}{c}{ Sum } & $\mathbf{9 0}$ & 12,22 \\
\hline
\end{tabular}

Source: Questionnaire Results, 2018.

\subsection{Rule of Law}

Besides, Muin Fahmal (2006: 270) explained that "in the concept of Administrative Law, the clean government is not positive law norms. But it can be synonymous with the government by following the law, namely Administrative Law as part of the Constitutional Law".

The rule of law is an absolute prerequisite for the administration of state life based on popular sovereignty. The rule of law means there is a constitutional guarantee that the implementation and enforcement in the law process are organized by the executive, legislative and judiciary powers. They will always rely on the authority determined by law. In this case, its authority functions are the basis for exercising legitimate power.

Legitimate power in the implementation of a democratic government is the guarantee to actualize the relation for the balanced law between people's sovereignty with the power government, based on the principle of the rule of law (rechts staat). The important elements in the rule of law (rechts staat), which is the characteristics rule of law include:

1) the guarantee for the government in carrying out its institutes and regulations

2) the guarantee for law protection of fundamental rights

3) a clear, equity, and consistent division of state power

4) law protection of equity agencies against acts of government.

The principle of government based on law is the universal elements from the law state concepts whatever the concept of state is. This principle does not mean the government has the responsibility to conduct the constitution and the principle of legality (wetmatigheid van bestuur). Although, it is a part of the guarantee for the implementation of equality principles for the law and principle.

By having this concept, the power government does not only conduct its authorities but also it is an authority power government. The power puts on the authority consists of Fahmal, Muin. (2006). Peran Asas-Asas Umum Pemerintahan yang Layak dalam Mewujudkan Pemerintaban yang Bersib.
Yogyakarta: UII Press, p. 270. 
the authority to decide independently and the authority of interpretation of the hidden norms.

Moreover, free power is not intended as an unlimited power. Free power is still based on law itself, namely in the form of unwritten laws which are the principles of proper governance as a basis for the implementation of government norms. Essentially the function of government is to carry out an efficient and effective bureaucratic process in service public, towards the actualization of civil society.

The participation society in the politic process and public policy formulations need systems and regulations law. Furthermore, to actualize the good governance must be followed by the commitment for the rule of law with the characters namely: The rule of law, the legal certainty, the responsive of law, the consistent and non-discriminatory law enforcement, equity independence, the legal framework must be equity and be applied indiscriminately including human rights.

Besides, in implementing the rule of law is as the accelerator for good governance and clean government of the government in Barru Regency that can be seen through the questionnaires. There are 90 (ninety) respondents that consist of government officials, subdistrict heads, village heads, and urban village heads in Barru Regency as following:

Table 2. The Classification of Respondents' Answers towards "The Rule of Law" as an Accelerator for Good Governance and Clean Government in Barru Regency

\begin{tabular}{lcc}
\hline \multicolumn{1}{c}{ Description } & F & Sum \\
\hline Very Effective & 16 & $\mathbf{P ~ ( \% )}$ \\
Effective & 32 & 17,78 \\
Less Effective & 33 & 36,56 \\
Ineffective & 9 & 35,67 \\
\hline \multicolumn{1}{c}{ Sum } & $\mathbf{9 0}$ & 10 \\
\hline
\end{tabular}

Source: Questionnaire Results, 2018.

\subsection{Effectivity}

Good governance is the most famous issue in the era of autonomy in the regions nowadays. The demand is very intensively carried out by the community to the government for implementing good governance and to increase the level of public knowledge and education and the influence of globalization.

Based on Bryant, the concept of decentralization demands one of the ways to develop region capacity, it can be applied to develop the implementation of regional autonomy in Indonesia. Also, Rondineli widely elaborated on the concept of decentralization. It is divided into four decentralization, they are "Deconcentration, Delegation to semi-autonomous and parastatal agencies, Devolution to region government, and non-government institutions".

Concerning the implementation of the regional government, the principle of good governance practice is to apply the principles of good governance in every policy and decision as well as actions in the implementation of public service functions.

\footnotetext{
8 Bryant and White. (1987). Manajemen Pembangunan untuk Negara Berkembang. Jakarta: LP3ES, p. n.p.
} 
All the citizens have a right to decide directly and legitimate representative institutions that represent their interests. All the participants are built based on freedom of association and expression and the capacity to participate and express the idea. The principles do not feel the freedom for society especially when the government makes the policy and the society is limited to proposals.

Next, the effectivity is as the accelerator for good governance and clean government of the government in Barru Regency that can be seen through the questionnaires. There are 90 (ninety) respondents that consist of government officials, sub-district heads, village heads, and urban village heads in Barru Regency as following:

Table 3. The Classification of Respondents' Answers towards “The Effectivity" as an Accelerator for Good Governance and Clean Government in Barru Regency

\begin{tabular}{lcc}
\hline \multicolumn{1}{c}{ Description } & F & Sum \\
& 18 & P (\%) \\
\hline Very Effective & 25 & 20 \\
Effective & 35 & 27,78 \\
Less Effective & 12 & 38,89 \\
Ineffective & $\mathbf{9 0}$ & 13,33 \\
\hline \multicolumn{1}{c}{ Sum } & & $\mathbf{1 0 0}$ \\
\hline
\end{tabular}

Source: Questionnaire Results, 2018.

\subsection{Accountability}

Accountability is the responsibility of the policies or service process that is conducted by the bureaucracy government. The implementation of good governance is the main regulation to actualize the society's aspiration in achieving the goals of nation and state.

In this context, the development and application of a participatory system are needed; transparency and proper accountability; clear and real; so that the implementation of regional government can take place in an efficient, successful, clean and responsible manner. The extent of the implementation of good governance in region governments, it is very dependent on the extent to be as participate.

Accountability has a meaning of responsibility which is the implementation of "Good Governance" or the management of good government. The idea is the public administration management that becomes the main issue in achieving "clean government".

Some pillars of good governance interact to form one to another that is related to each other for instance Government, Citizen, and Business or State, Society and Private Sector. Basically, the pillar has the consequence of accountability for the public or society, especially for stakeholders that cover three pillars as the perpetrators of "bow to govern" in their activities.

The New Order bequeath for the low instrument of responsibility of public institutions and it almost did not leave the transparent institutional mechanisms and explore the values of community participation in deciding the policies for the government. Society commonly is as objects of development and it does not work in a partnership pattern in improving government performance and accountability.

The society participation is proud of in development planning through "bottom-up and top-down planning" which is the Discussion Section Village Development by LKMD. The forms of social participation in the past which are essential "mobilization" or at least 
the type of participation "statutory", the participation is formatted by the government; which in the end is also still "put up on" for region democratization in planning.

The constitution 22 of 1999 year and constitution 25 of 1999 year, it still doubts in implementation. However, the constitution 22 of 1999 year and the constitution 25 of 1999 year about the regional autonomy and Regional Fiscal Balance implicity and explicitly have been stated that it needs the responsibility of regional for all the process of actions in creating the policies to achiever the regional accountability instruments.

As explained above, this is the most important part to organize as the instrument for good governance. Besides, the constitution 28 and 1999 year about clean government and free of corruption governance and Presidential Instruction No. 7 of 1999 provides the principles of good governance to implement it especially for the responsibility, accountability, transparency, and participation for public institution particular regional government.

The essence for implementing regional autonomy is to decrease the role of the central government towards region strategy development which is to know that every region particularly regency/city has the characteristic to develop every region. The review begins for the implementation of regional autonomy which is begun the meaning of accountability itself in the regional government environment, then the need for public disclosure or openness in management.

Furthermore, it explains about the managerial aspects through the concept of New Public Management, the ways region government must have the autonomy of the right organizational structure, the openness, and the performance measurements related to the organizational structure. Next, the agenda has been prepared by the central government, especially those related to the regions in the context of the implementation of good governance.

The principles of accountability are as the accelerator for good governance and clean government of the government in Barru Regency that can be seen through the questionnaires. There are 90 (ninety) respondents that consist of government officials, subdistrict heads, village heads, and urban village heads in Barru Regency as following:

Table 4. The Classification of Respondents' Answers towards "The Principles of Accountability" as an Accelerator for Good Governance and Clean Government in Barru Regency

\begin{tabular}{lcc}
\hline \multicolumn{1}{c}{ Description } & F & Sum \\
& Very Effective & $\mathbf{P ~ ( \% )}$ \\
Effective & 27 & 14,44 \\
Less Effective & 34 & 30 \\
Ineffective & 16 & 50,67 \\
\hline \multicolumn{1}{c}{ Sum } & $\mathbf{9 0}$ & 12,09 \\
\hline
\end{tabular}

Source: Questionnaire Results, 2018.

\subsection{Strategic Vision}

The strategic vision is strategic to face the future. Leaders and societies have a broad and far-reaching perspective on good governance and human development, and the needed to realize this development. Therefore, they must also have an understanding of the historical, cultural, and social complexities that are the basic perspective of it. 
To apply good governance can be conducted by the steps with its capacity for region government, civil society, and marketing mechanisms. One of the strategies implements good governance in Barru Regency through managing public service. Public service is an important part of the stakeholder of good governance elements. For the official public, the elements of citizen and business sectors have the same important items against the repairing of performance public service.

Based on the researcher, there are three reasons that the implementation of public services can encourage the practice of good governance in Barru Regency, namely:

1) Improving the performance of public services is an important part by stakeholders, namely the government, citizens, and the business sector.

2) Public services are the domain of the three elements for the government to conduct intensive interactions.

3) Values have characterized the practice of good governance that has been interpreted more easily and clearly through public services.

The phenomenon of public service by the government bureaucracy has problems, for example, the complicated service procedures, uncertainty of time and prices that are difficult to reach naturally by the public. This cause makes unbelievable bureaucracy so that people look for alternative ways to get services through certain methods, for instance, the people need to pay additional costs.

In the part of the service public, another problem is often the server abuse their dignity as citizens. The public is placed as a client who needs the help of bureaucratic officials, so they must submit to the bureaucratic provisions and the wants of their officials. It happens because the culture is not a service culture, but rather leads the culture of power.

The efforts realize good governance with public services that may not be new things. But the relationship between the concept of good governance (good governance) with the concept of public service (public service) is certainly quite clear.

Another argument that proves how important public services are. It relates to the level of people's welfare. It is clear enough because of the awareness of bureaucrats for developing regions to provide the best service is still very low.

Based on the explanation, the principle of strategic vision is the accelerator for good governance and clean government at Barru Regency that can be seen through the questionnaires. There are 90 (ninety) respondents that consist of government officials, subdistrict heads, village heads, and urban village heads in Barru Regency as following:

Table 5. The Classification of Respondents' Answers towards "The Principles of Strategic Vision" as an Accelerator for Good Governance and Clean Government in Barru Regency

\begin{tabular}{lcc}
\hline \multicolumn{1}{c}{ Description } & F & Sum \\
\hline Very Effective & 7 & $\mathbf{P ~ ( \% )}$ \\
Effective & 22 & 7,78 \\
Less Effective & 43 & 22,44 \\
Ineffective & 18 & 47,78 \\
\hline \multicolumn{1}{c}{ Sum } & $\mathbf{9 0}$ & 20 \\
\hline
\end{tabular}

Source: Questionnaire Results, 2018. 


\section{Conclusion}

Barru Regency Governance in implementing good governance and clean government are still influenced by several factors, for instance, the regional governments that have not been able to be equity and optimally. It has not been able to uphold the rule of law, has not been able to work effectively, has not been able to work in accountability, and has not been able to formulate and implement a strategic vision.

For the Regional Government of Barru Regency can have the capacity to carry out good governance and clean government, it must follow the following ways:

1) The regional government must be able to act equity properly and maximally to the society;

2) The region governments must uphold the rule of law;

3) The region government must work effectiveness;

4) The region governments must work accountably, collectively; and

5) The region governments must formulate and implement a strategic vision that is with the regional potential.

\section{Acknowledgments}

I thank the editorial team of Amsir Law Jurnal for publishing my writing in volume 1 (2), April 2020.

\section{Reference}

Books with an author:

Bryant and White. (1987). Manajemen Pembangunan untuk Negara Berkembang. Jakarta: LP3ES Butarbutar.

Elisabeth Nurhaini. (2018). Metode Penelitian Hukum (Langkah-Langkah untuk. Menemukan Kebenaran dalam Ilmu Hukum), Bandung: PT. Refika Aditama.

Fahmal, Muin. (2006). Peran Asas-Asas Umum Pemerintahan yang Layak dalam Mewujudkan Pemerintahan yang Bersih. Yogyakarta: UII Press.

Tangkilisan. (2005). Manajemen Publik. Jakarta: Grasindo.

Tjokroamidjojo, Bintoro. (1984). Pengantar Administrasi pembangunan. Jakarta: LP3ES.

Uchana, Efendy Onong. (2005). Ilmu Komunikasi Teori dan Praktek. Bandung: Remaja Rosda Karya.

\section{Conflict of Interest Statement:}

The author declares that the research was conducted in the absence of any commercial or financial relationships that could be construed as a potential conflict of interest.

Copyright (C) 2020 ALJ. All rightsreserved. 